\title{
Tests for Mutagenicity in Salmonella and Covalent Binding to DNA and Protein in the Rat of the Riot Control Agent o-Chlorobenzylidene Malononitrile (CS)
}

\author{
Albert von Däniken, Urs Friederich, Werner K. Lutz, \\ and Christian Schlatter \\ Institute of Toxicology, Swiss Federal Institute of Technology and University of Zurich, \\ CH-8603 Schwerzenbach, Switzerland
}

\begin{abstract}
The aim of this study was to determine whether o-chlorobenzylidene malononitrile (CS) exhibits any genotoxic activity towards Salmonella or mammalian DNA in vivo. CS was synthesized with a $\left[{ }^{14} \mathrm{C}\right]-l a b e l$ at the benzylic carbon atom. It was administered i.p. at a dose level of $13 \mathrm{mg} / \mathrm{kg}$ $(1 \mathrm{mCi} / \mathrm{kg})$ to young adult male rats. Liver and kidney DNA was isolated after 8,25 , and $75 \mathrm{~h}$. The radioactivity was at (liver, 8 and $75 \mathrm{~h}$ ) or below (all other samples) the limit of detection of $3 \mathrm{dpm}$. Therefore, a possible binding of CS to DNA is at least $10^{5}$ times lower than that of the strong hepatocarcinogen aflatoxin $B_{1}$, and 4,000 times lower than that of vinyl chloride. In contrast to this lack of DNA binding, but in agreement with the chemical reactivity of CS, a binding to nuclear proteins could be detected with specific activities ranging between 50 and $121 \mathrm{dpm} / \mathrm{mg}$ for liver and between 3 and $41 \mathrm{dpm} / \mathrm{mg}$ for kidney. Protein binding could well be responsible for its pronounced cytotoxic effects. CS was also tested in the Ames Salmonella/microsome assay. Strains TA 1535, TA 1537, TA 1538, TA 98, and TA 100 were used with or without pre-incubation. Only with strain TA 100 and only without pre-incubation, a doubling of the number of revertants was detectable at the highest dose levels used, 1,000 and 2,000 $\mu \mathrm{g}$ CS per plate. With pre-incubation of TA 100 with CS, a slight increase of the number of revertants was seen at 100 and $500 \mu \mathrm{g}$ per plate, and a subsequent fall below control values at $1,000 \mu \mathrm{g}$. A check for the number of surviving bacteria revealed a strong bacteriotoxicity of the higher doses of CS so that the calculated mutation frequencies, i.e., the number of revertants per number of surviving bacteria, increased with doses up to $500 \mu \mathrm{g}$. This toxicity could be counteracted in part by the addition of increasing amounts of rat liver microsomes. In the view of these results, and taking into account the rare and low exposure of man, it is concluded that $\mathrm{CS}$ will not create a risk for the induction of point mutations or of carcinogenic processes mediated by DNA binding.
\end{abstract}

Key words: o-Chlorobenzylidene malononitrile - Riot control agents DNA Binding - Salmonella/microsome assay - Carcinogens - Mutagens 
A. von Däniken et al.

\section{Introduction}

o-Chlorobenzylidene malononitrile (CS) is a lacrimating riot control agent used in the form of an aerosol or smoke. Its acute toxicity has been studied in various animal species (Gaskins et al. 1972; Ballantyne and Swanston 1978; Cucinell et al. 1971), but a possible carcinogenic effect was merely discussed (Schrempf 1978; Anon 1973; Jones 1973; Sanford 1976). In one report which is not easily available, an inhalation study with a 2-year-period of observation is described: either 100 (50 males and 50 females) A/J strain mice or 100 Sprague-Dawley-Wistar rats were exposed to $21 \mathrm{mg} / \mathrm{m}^{3}$ aerolized CS for 2.5 or $25 \mathrm{~min}$ daily for 20 days ( 5 days a week for 4 weeks). After $6,12,18$, and 24 months, groups of animals were sacrificed and examined for lung tumors grossly and microscopically. No significant increase was observed (McNamara et al. 1973). However, CS was found to be active in suppressing non-specific esterase activity in mouse skin sebaceous gland (Barry et al. 1972). This assay was introduced as a screening test for carcinogenicity. Although this test is not generally accepted due to the lack of a sufficient theoretical base and incomplete validation (Purchase et al. 1976), these controversial findings with CS call for further investigations on putative carcinogenic activity.

There is much evidence that covalent binding of a chemical to DNA is the first step in the induction of a tumor by a genotoxic agent, and a useful quantitative correlation between carcinogenic potency and in vivo DNA binding could be shown for hepatocarcinogens and liver DNA (Lutz 1979) as well as for non-selected tissues (Lutz 1981).

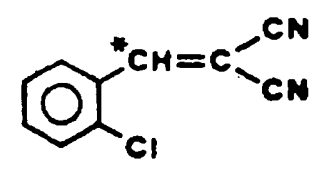

$\mathrm{CS}$, as an activated olefin, reacts preferably with SH-groups of proteins (Cucinell et al. 1971). It also reacts with amino groups such as in lysine (Jones 1972) and it cannot be excluded that it may also react with DNA. In 5\% aqueous ethanol, CS is hydrolysed to o-chlorobenzaldehyde and malononitrile with a half life of about $12 \mathrm{~min}$ at $25^{\circ} \mathrm{C}$ (unpublished results). The aldehyde by itself could in principle also react with biological macromolecules, but no data are available to indicate such activity. Besides, no other metabolites are suspected of undergoing a covalent interaction with macromolecules.

In an attempt to detect covalent interactions of CS or its metabolites in vivo, we administered $\left[{ }^{14} \mathrm{C}\right]$-labelled $\mathrm{CS}$ to rats, isolated nuclei from various organs and measured the radioactivity on nuclear protein or DNA. The radiolabel was introduced into the benzylic carbon atom (denoted with ${ }^{*}$ in the structural formula), so that the electrophilic aldehyde metabolite was still radioactive.

In addition, we performed the Salmonella/microsome assay according to Ames et al. (1975) with and without pre-incubation (Nagao et al. 1977), in order to obtain, in microorganisms, additional information on possible DNA alterations by $\mathrm{CS}$. 


\section{Materials and Methods}

Chemicals and General Methods. o-Chloroiodobenzene was purchased from Eastman Kodak, Rochester, NY, USA, hydroxyapatite (DNA-grade Bio Gel HTP) from Bio-Rad, Richmond, CA, USA, sodium dodecylsulfate (SDS) from Sigma, St. Louis, MO, USA, nutrient broth and bacto-agar from Difco, Detroit, MI, USA, aroclor 1254 from Analabs, Inc., North Haven, CT, USA. Silicagel 60 with a particle size $0.063-0.2 \mathrm{~mm}$ was from Merck, Darmstadt, FRG, who also supplied all standard reagents of the highest purity available. $\left[{ }^{14} \mathrm{C}\right]$-labelled sodium carbonate $(50 \mathrm{mCi})$ with a specific activity of $57.5 \mathrm{mCi} / \mathrm{mMol}$ was purchased from the Radiochemical Centre, Amersham, England. It was diluted with $300 \mathrm{mg}$ inactive $\mathrm{Na}_{2} \mathrm{CO}_{3}$ to a specific activity of $14 \mathrm{mCi} / \mathrm{mMol}$.

Radioactivity measurements were carried out in Insta-Gel (Packard Instruments, Downers Grove, IL, USA) in a liquid scintillation counter, Packard Tri Carb 460 CD.

Synthesis of 0 -Chloro- $\left[{ }^{14} \mathrm{C}\right]$ Benzylidene Malononitrile. The $\left[{ }^{14} \mathrm{C}\right]-\mathrm{CS}$ was synthesized with a $\left[{ }^{14} \mathrm{C}\right]$-label at the benzylic carbon atom according to Harrison et al. (1978). o-Chloroiodobenzene was first converted in a Grignard reaction to o-chlorobenzene magnesium iodide, and $50 \mathrm{mCi}$ $\left[{ }^{14} \mathrm{C}\right] \mathrm{O}_{2}$, generated by concentrated sulfuric acid from $\mathrm{Na}_{2}\left[{ }^{14} \mathrm{C}\right] \mathrm{O}_{3}$ was used to produce o-chloro $\left[{ }^{14} \mathrm{C}\right]$ benzoic acid. After reduction to $\mathrm{o}$-chloro $\left[{ }^{14} \mathrm{C}\right]$ benzyl alcohol and oxidation to o-chloro $\left[{ }^{14} \mathrm{C}\right]$ benzaldehyde, $\left[{ }^{14} \mathrm{C}\right]$-CS was obtained by condensation with malononitrile. Purification by silicagel column chromatography and recristallisation from methylene chloride: petroleum ether $\left(40^{\circ}-60^{\circ}\right) 1: 20$, resulted in $5.4 \mathrm{mCi}\left[{ }^{14} \mathrm{C}\right]-\mathrm{CS}$ with a specific activity of $14 \mathrm{mCi} / \mathrm{mMol}$. The radiochemical purity was $>97 \%$ as checked by thin layer chromatography on silicagel plates with methylene chloride: petroleum ether $1: 1$.

Animals and Treatments. Six male rats (ZUR:SIV-Z, Sprague-Dawley derived, 160-190 g) were obtained from the Kantonales Tierspital, Zurich, Switzerland. Nafag laboratory chow No. 890 (Nafag AG, Gossau, Switzerland) and tap water were provided ad libitum. The animals were given a single i.p. injection of $100 \mu \mathrm{l}$ of a solution of $24 \mathrm{mg} \mathrm{[}\left[{ }^{14} \mathrm{C}\right]-\mathrm{CS} / \mathrm{ml}$ polyethylene glycol 300, prepared immediately before administration. In this solvent and within this short time, CS is chemically stable as checked by thin-layer chromatography. The total radioactivity administered was in the range of $0.85-1.14 \mathrm{mCi} / \mathrm{kg}$ body weight, corresponding to $11-15 \mathrm{mg} \mathrm{CS} / \mathrm{kg}$, which is about a quarter of the $\mathrm{LD}_{50}$ i.p. for male rats (Ballantyne and Swanston 1978). The animals were kept individually in metabolism cages for collection of urine. At 8,25, and $75 \mathrm{~h}$ after the injection, two animals were killed by open heart puncture under ether anaesthesia. Liver and kidney were excised and cell nuclei were prepared immediately.

Preparation of Nuclei. Nuclei of liver and both kidneys were isolated in the cold according to Viviani et al. (1978), with some modifications. The organs were washed in $0.25 \mathrm{M}$ sucrose-TKM (50 mM Tris- $\mathrm{HCl}, \mathrm{pH} 7.5,2.5 \mathrm{mM} \mathrm{KCl}, 5 \mathrm{mM} \mathrm{MgCl} 2$ ). $10 \mathrm{~g}$ liver and about $1.5 \mathrm{~g}$ kidney were homogenized, respectively, in $30 \mathrm{ml}$ and $12 \mathrm{ml} 0.25 \mathrm{M}$ sucrose-TKM in a loose fitting Potter-Elvehjem type homogenizer with 10 up-and-down strokes at $500 \mathrm{rpm}$. The homogenates were spun for $20 \mathrm{~min}$ at $2,000 \mathrm{~g}$, the pellets were resuspended in $30 \mathrm{ml}$ and $12 \mathrm{ml} 0.25 \mathrm{M}$ sucrose-TKM and centrifuged for 5 $\mathrm{min}$ at $1,000 \mathrm{~g}$. The resulting pellets were finally resuspended in $30 \mathrm{ml}$ and $15 \mathrm{ml} 2.2 \mathrm{M}$ sucrose-TKM. $1.5 \mathrm{ml}$ of $2.3 \mathrm{M}$ sucrose-TKM was underlayered and the tube centrifuged for $20 \mathrm{~min}$ at $80,000 \mathrm{~g}$ in a Sorvall AH-627 swinging bucket rotor to spin down the nuclei.

Isolation and Purification of DNA from Nuclei. DNA was isolated from the nuclei according to procedure 1 of Markov and Ivanov (1974). One half to $1 \mathrm{mg}$ purified DNA was obtained per $\mathrm{g}$ organ. DNA was dissolved in $4 \mathrm{ml}$ of $0.014 \mathrm{M}$ sodium phosphate buffer, $\mathrm{pH} 6.8$, and the concentration was determined on the basis of a UV absorbance of 20 at $260 \mathrm{~nm}$ for a solution of $1 \mathrm{mg} / \mathrm{ml}$. A maximal contamination with $0.1 \%$ nuclear protein was determined from control experiments where the protein was labelled with $\left[{ }^{35} \mathrm{~S}\right]$ after feeding of $\left[{ }^{35} \mathrm{~S}\right]$ methionine and by measuring the specific activity of purified DNA and nuclear protein.

Purification of Nuclear Protein. Nuclear protein was precipitated from the first chloroform : phenol : isoamyl alcohol extract by adding $20 \mathrm{ml}$ acetone and spinning for $5 \mathrm{~min}$ at $1,000 \mathrm{~g}$. The pellet was dissolved in $2 \mathrm{ml}$ of $1 \% \mathrm{SDS}, 0.014 \mathrm{M}$ sodium phosphate, $\mathrm{pH} 6.8$, precipitated again with $20 \mathrm{ml}$ 
acetone and centrifuged. This procedure was repeated once. Dialysis overnight against 1,000 volumes of water and one more precipitation resulted in no further changes in the specific activity of the proteins. The pellets were dissolved in $5 \mathrm{ml} 1 \% \mathrm{SDS}, 0.014 \mathrm{M}$ sodium phosphate, $\mathrm{pH}$ 6.8. One milliliter was taken for the radioactivity measurement. The amount of protein was measured according to Lowry et al. (1951).

Salmonella/Microsome Mutagenicity Assay According to Ames et al. (1975). Salmonella typhimurium strains TA 1535 , TA 1537 , TA 1538, TA 98, and TA 100 were obtained from B. N. Ames. The procedure of Ames et al. (1975) was modified in the following steps: To a stationary phase culture of the tester strains which had been checked for the genetic markers according to Ames et al. (1975), a sterile solution of glycerol was added to give a final concentration of $10 \%(\mathrm{v} / \mathrm{v})$. The cultures were stored in aliquots of $0.5 \mathrm{ml} \mathrm{at}-80^{\circ} \mathrm{C}$. These frozen permanents were thawed immediately prior to use, $0.2 \mathrm{ml}$ were inoculated into $10 \mathrm{ml}$ nutrient broth supplemented with $10 \mu \mathrm{g} / \mathrm{ml} \mathrm{L}$-histidine-HCl and incubated for $5 \mathrm{~h}$ in a shaking water bath $\left(100 \mathrm{cycles} / \mathrm{min} ; 37^{\circ} \mathrm{C}\right)$. The number of living cells in the 5 -h-culture was determined by diluting the cell suspension one million fold with $0.85 \% \mathrm{NaCl}$ and plating on complete medium $(0.8 \%$ nutrient broth, $0.5 \% \mathrm{NaCl}, 1.5 \%$ Bacto-Agar).

Livers of aroclor 1254-induced adult male rats $(200 \mathrm{~g})$ were homogenized in three volumes 0.25 $\mathrm{M}$ sucrose, $0.01 \mathrm{M}$ Tris- $\mathrm{HCl}$ buffer, $\mathrm{pH} \mathrm{7.4}$. One half milliliter $\mathrm{S}-9 \mathrm{mix}$, containing various concentrations of undiluted S-9, was used per plate. CS was dissolved in dimethylsulfoxide and $50 \mu \mathrm{l}$ solution was added per plate. Both the plate incorporation assay of Ames et al. (1975) and the pre-incubation method (Nagao et al. 1977) were used. S-9 mix or buffer alone $(1.5 \mathrm{ml})$, cells $(0.3 \mathrm{ml})$, and CS $(0.15 \mathrm{ml})$ were mixed in this order. Upon addition of $500 \mu \mathrm{g} \mathrm{CS}$ or more, a white precipitate formed in the cell suspension, indicating the limits of water solubility of CS. Six milliliter soft agar containing $0.05 \mathrm{mM}$ of each biotin and histidine were added directly or after pre-incubation for 20 $\min$ at $37^{\circ} \mathrm{C}$ in a shaking water bath. After vigorous mixing, $2.5 \mathrm{ml}$ of the suspension was poured onto each of three replicate plates.

For the determination of possible bactericidal effects of CS, different dilutions of the 5-h-culture with $0.85 \% \mathrm{NaCl}\left(10^{2} \mathrm{x}-2 \cdot 10^{5} \mathrm{x}\right.$, depending on the concentration of $\mathrm{CS}$ and S-9) were mixed with buffer, test compound and S-9 according to the test protocol for the mutagenicity assays. The cells were suspended in top agar containing $0.05 \mathrm{mM}$ biotin and $60 \mu \mathrm{g} / \mathrm{ml} \mathrm{L}$-histidine-HCl to allow also histidine-auxotrophic cells to grow.

As positive controls for the assays without rat liver S-9 added, 2-Nitrofluorene (2-NF; $15 \mu \mathrm{g}$ per plate) was used for strains TA 1538 and TA 98 , sodium azide $\left(\mathrm{NaN}_{3} ; 5 \mu \mathrm{g}\right.$ per plate) for strains TA 1535 and TA 100, and 9-aminoacridine (9-AA; $100 \mu \mathrm{g}$ per plate) with strain TA 1537. For the assays with rat liver $\mathrm{S}-9$ added, 2-aminoanthracene (2-AA; $20 \mu \mathrm{g}$ per plate for the strains TA 1535, TA $1537,10 \mu \mathrm{g}$ for TA 1538,5 or $10 \mu \mathrm{g}$ for TA 98, TA 100 ) was used as a positive control for all strains.

\section{Results}

Kinetics. The administered radioactivity rapidly appeared in the urine of the treated rats. Within $8 \mathrm{~h}, 75 \%$ of the dose was metabolized to water-soluble compounds and excreted, and after $75 \mathrm{~h}$ this fraction had increased to $84 \%$. The radioactivity in the organ homogenates, $8 \mathrm{~h}$ after the administration, was in the range of $0.07-0.25 \%$ of the dose in the liver, and $0.014-0.1 \%$ in the kidney. Similar levels were found after $25 \mathrm{~h}$, whereas after $75 \mathrm{~h}$, the corresponding values had decreased to about a third.

Protein Binding. The highest activity of CS bound to nuclear protein was determined to be $121 \mathrm{dpm} / \mathrm{mg}$ protein in the liver and $41 \mathrm{dpm} / \mathrm{mg}$ in the kidney. Liver-protein binding was highest after $25 \mathrm{~h}$, whereas the specific activity of 
Table 1. Binding of CS to rat liver and kidney nuclear protein and DNA, 8,25, and $75 \mathrm{~h}$ after i.p. administration of $\left[{ }^{14} \mathrm{C}\right]$-labelled CS. All figures are mean values obtained from two animals

\begin{tabular}{|c|c|c|c|c|c|c|}
\hline & \multicolumn{6}{|c|}{ Time between administration and sacrifice (h) } \\
\hline & \multicolumn{2}{|l|}{8} & \multicolumn{2}{|l|}{25} & \multicolumn{2}{|l|}{75} \\
\hline & Liver & Kidney & Liver & Kidney & Liver & Kidney \\
\hline $\begin{array}{l}\text { Specific radioactivity } \\
\text { of nuclear protein }(\mathrm{dpm} / \mathrm{mg})\end{array}$ & 99 & 41 & 121 & 26 & 50 & 3 \\
\hline $\begin{array}{l}\text { Amount of DNA in } \\
\text { scintillation vial (mg) }\end{array}$ & 4.59 & 1.17 & 4.65 & 1.69 & 4.61 & 0.87 \\
\hline $\begin{array}{l}\text { Gross activity (cpm) } \\
\text { Counting time: } 5 \times 40 \mathrm{~min}\end{array}$ & 16.8 & 13.9 & 15.0 & 14.3 & 17.0 & 14.7 \\
\hline $\begin{array}{l}\text { Specific activity } \\
\text { of DNA (dpm/mg)* }\end{array}$ & $0.90 \pm 0.72$ & $<2.96$ & $<1.07$ & $<2.37$ & $0.96 \pm 0.72$ & $<5.25$ \\
\hline $\begin{array}{l}\text { Covalent binding Index, } \\
\mu \mathrm{mol} \text { chemical bound } / \mathrm{n}\end{array}$ & $\begin{array}{l}0.12 \pm 0.09 \\
\text { DNA nucleoti }\end{array}$ & $<0.38$ & $<0.17$ & $<0.37$ & $0.16 \pm 0.12$ & $<0.85$ \\
\hline mmol chemical & eight & & & & & \\
\hline
\end{tabular}

* These values are calculated on the basis of a background activity of $13.8 \pm 0.8 \mathrm{cpm}$ (one standard deviation, S.D.) derived from the background radioactivity of inactive DNA samples from 12 different control experiments. By setting the confidence limits to three S.D. and with a counting efficiency of $73 \%$, a limit of detection of $3.3 \mathrm{dpm}$ results

kidney protein decreased already after $8 \mathrm{~h}$ and was at the limit of detection at $75 \mathrm{~h}$ (Table 1).

$D N A$ Binding. In contrast to the findings with protein, a radioactivity just above the limit of detection (liver $8 \mathrm{~h}$ and $75 \mathrm{~h}$ ) or no significant radioactivity at all (all other cases) could be detected on the purified DNA (Table 1).

Mutagenicity Data. Only with strain TA 100 was a very weak mutagenic effect detectable. As much as 1 or $2 \mathrm{mg} \mathrm{CS}$ was needed in order to double the number of revertants in the standard plate assay (Table 2). Upon pre-incubation, a slight increase of the number of revertants could be detected already with $100 \mu \mathrm{g}$ (Table 3).

This weak mutagenic effect was not seen upon addition of $10 \%$ S-9 and an additional series of experiments using also $3 \%$ or $30 \%$ S-9 revealed that CS can best exert its weak mutagenicity in the absence of S-9, be this without (Fig. 1) or with (Fig. 2) pre-incubation:

Without pre-incubation (Fig. 1), there was a linear dose-effect relationship between 500 and $2,000 \mu \mathrm{g}$ per plate. The addition of an S-9 mix containing $3 \%$ or $10 \%$ S-9 reduced the mutagenic effect while $30 \%$ S-9 completely abolished mutagenicity. The higher number of control revertants per plate with increasing S-9 concentrations can be explained by a growth stimulation by traces of histidine present.

Pre-incubation with high doses of CS in all strains resulted in a decrease of the number of revertants (Table 3 ). This sign of cytotoxic activity of CS is not seen 
A. von Däniken et al.

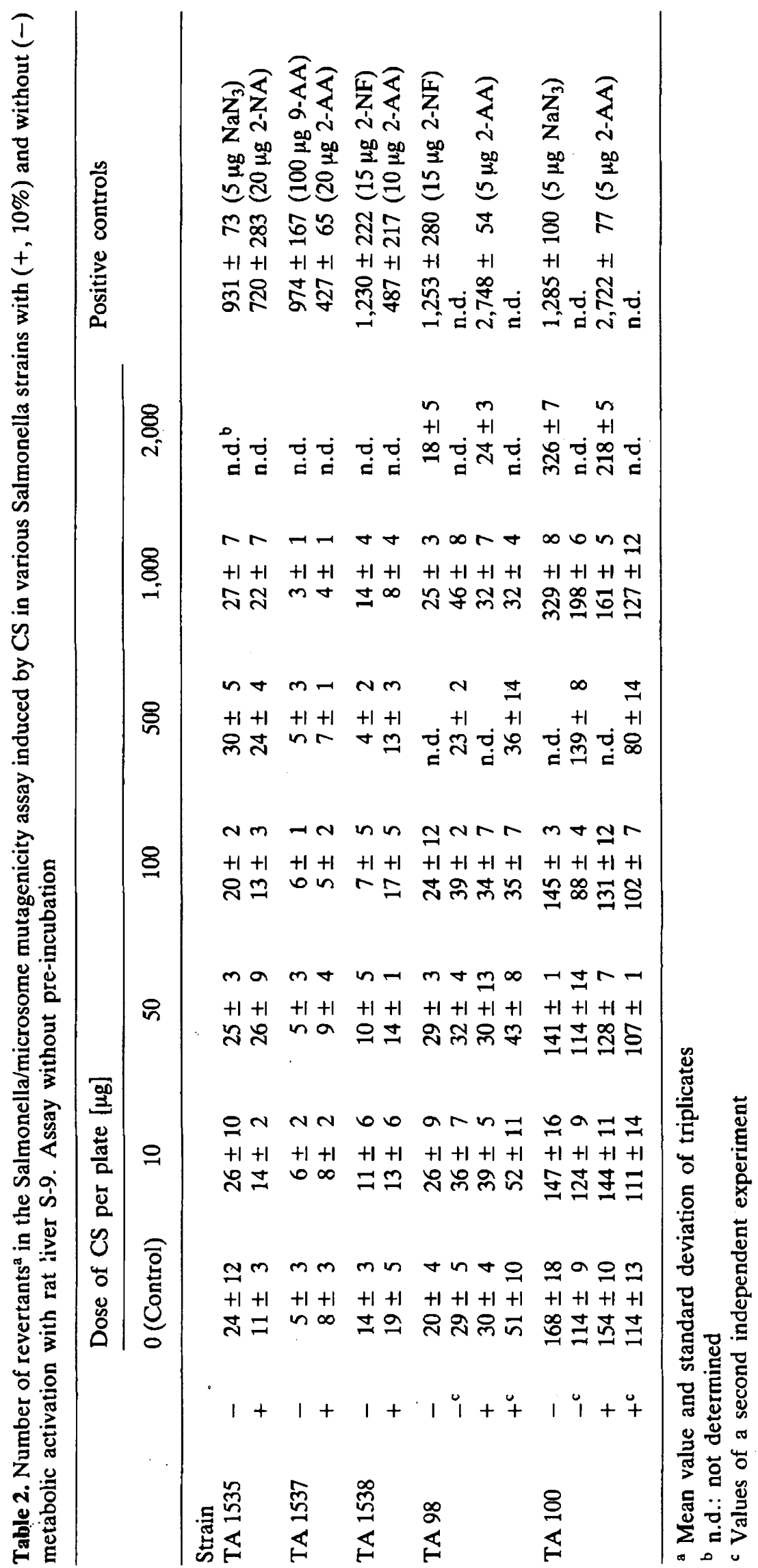




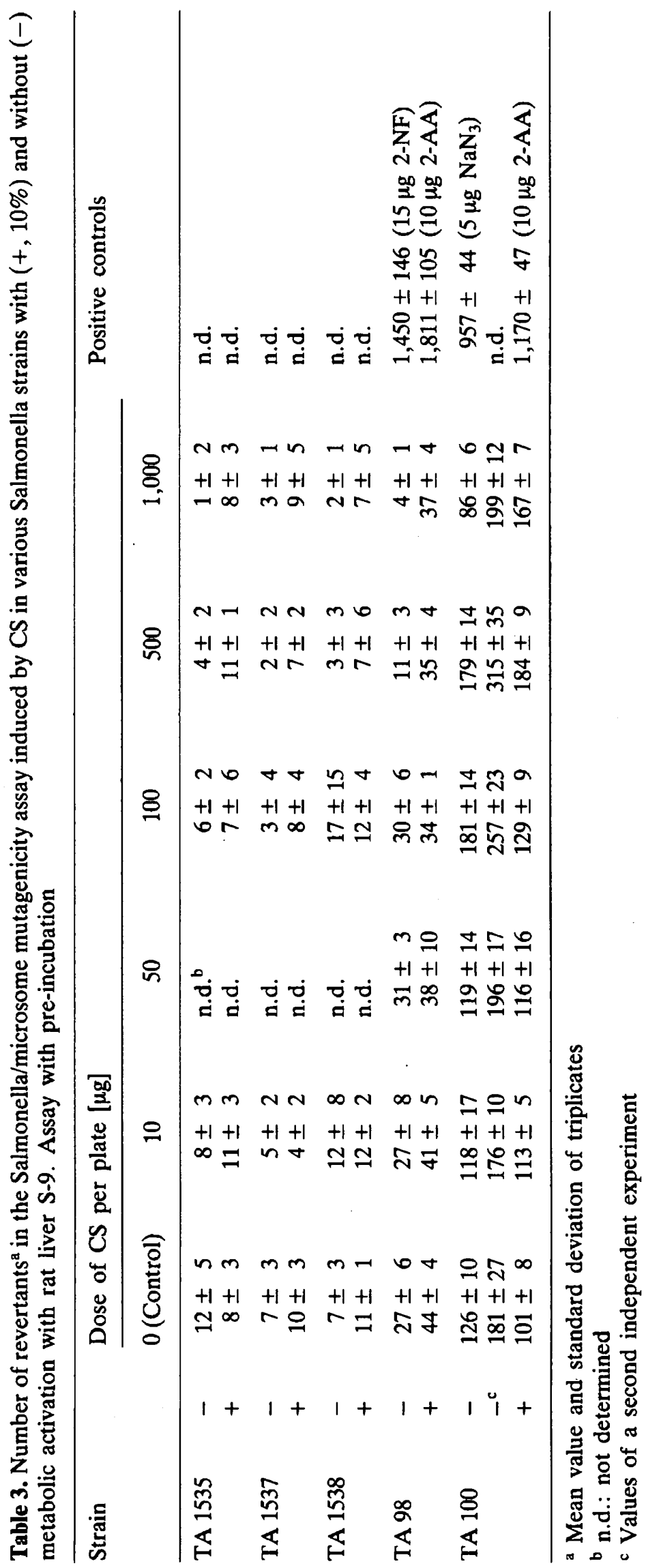


A. von Däniken et al.

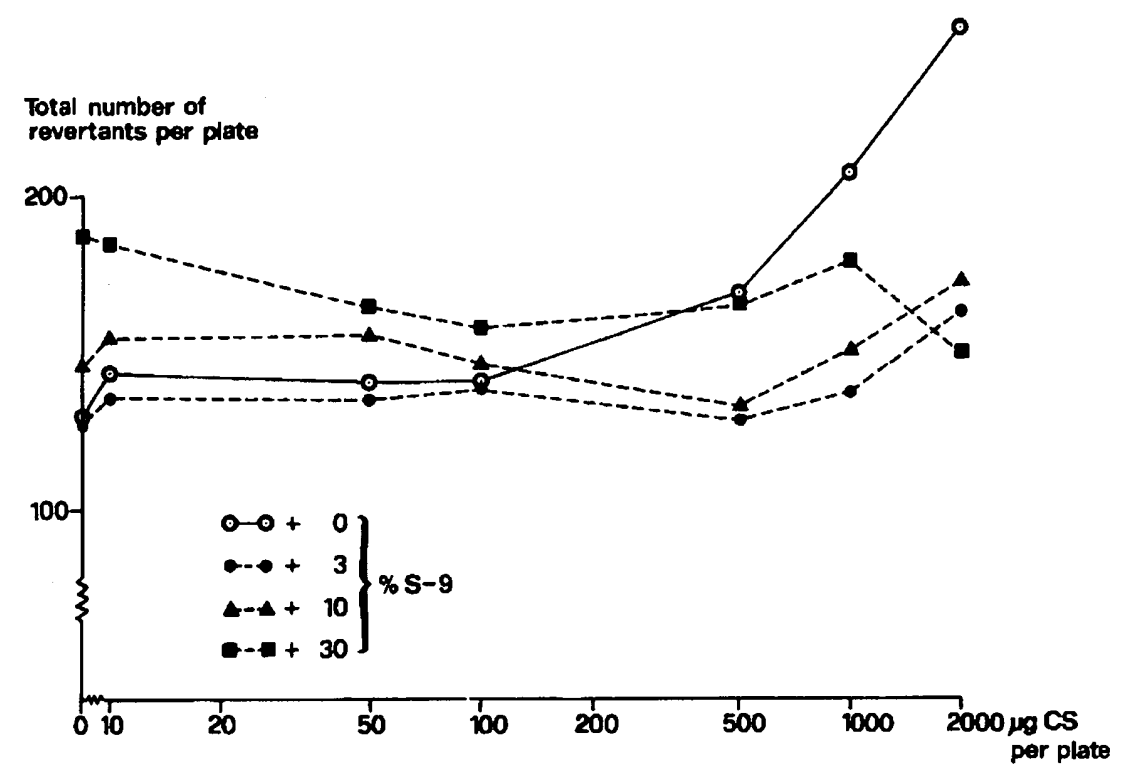

Fig. 1. Mutagenicity of CS for TA 100 in the plate incorporation assay using different concentrations of S-9. Mean values of three replicate plates are given

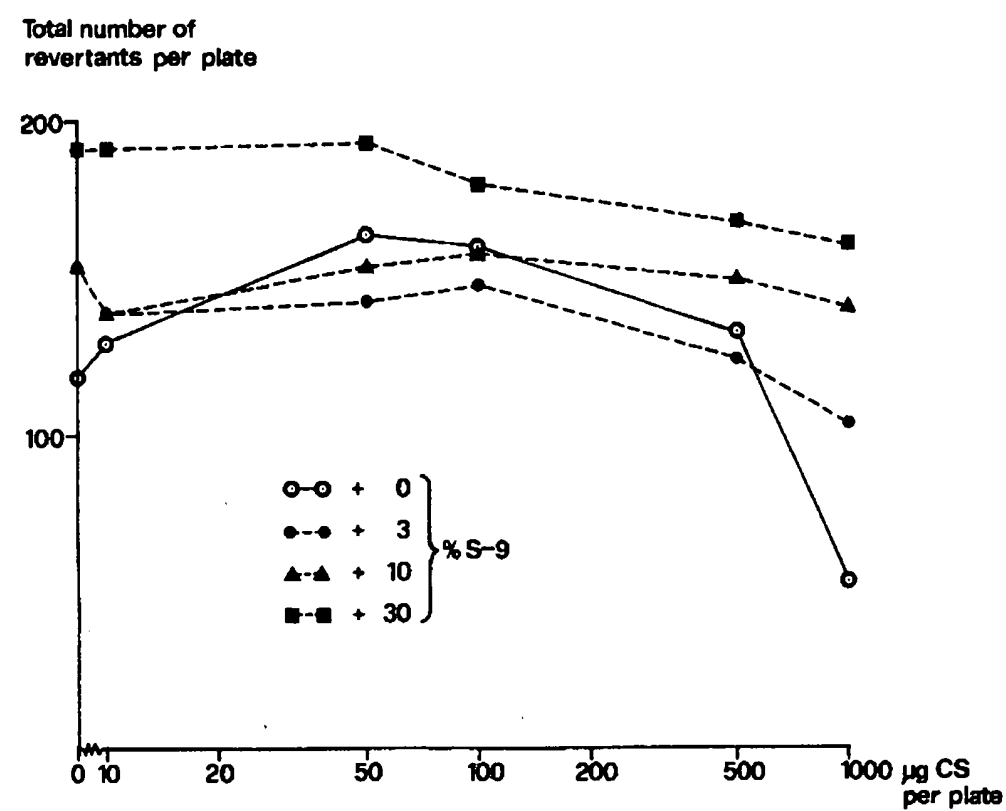

Fig. 2. Mutagenicity of CS for TA 100 after pre-incubation for $20 \mathrm{~min}$ at $37^{\circ} \mathrm{C}$ and using different concentrations of S-9. Mean values of three replicate plates are given

when $10 \%$ S-9 was added to the incubation mixture. It is probable that under these conditions CS reacts preferentially with the liver proteins, so that less is available to penetrate the bacterial cell wall. In the more extended studies with TA 100 and varying doses of S-9 (Fig. 2), a slight increase in the number of revertants resulted already between 10 and $100 \mu \mathrm{g}$ CS per plate. This rise was followed by a decrease leading to an approximate $50 \%$ reduction of the total 


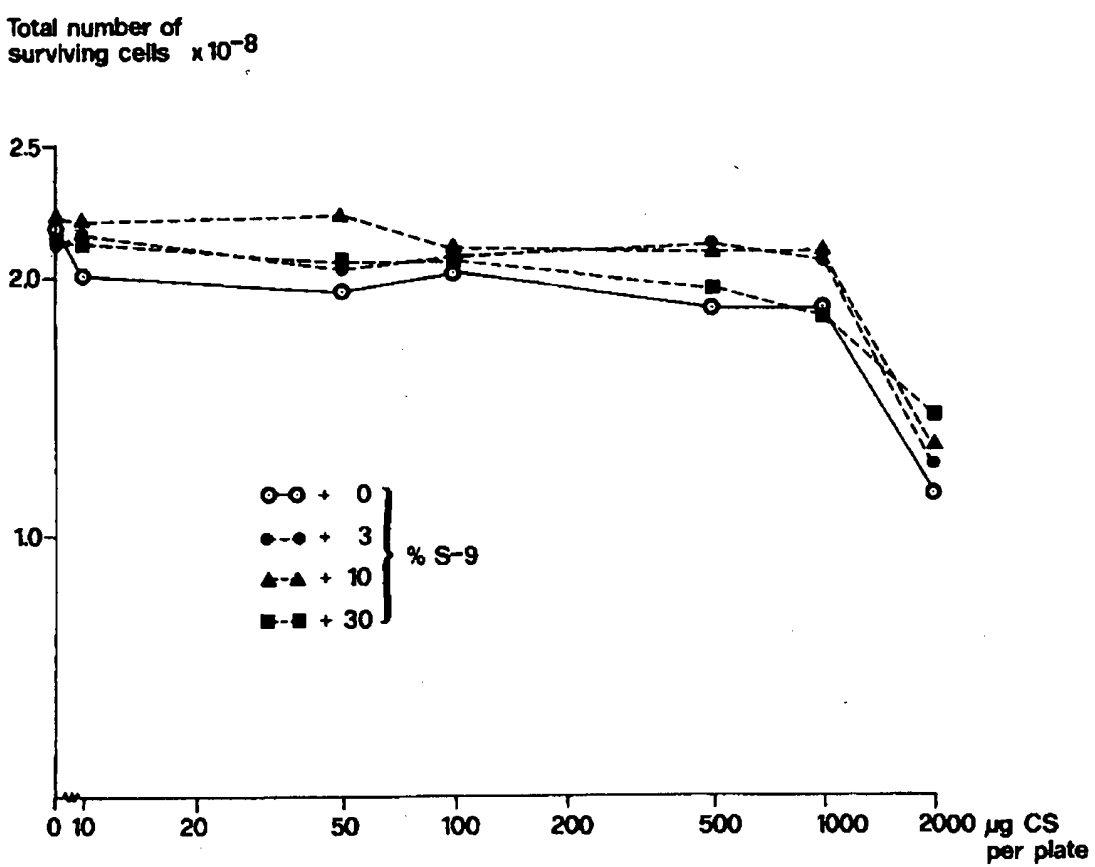

Fig. 3. Bactericidal effects of CS. CS was plated directly with appropriate dilutions of bacteria and different concentrations of S-9 on minimum medium plates supplemented with additional histidine. Mean values of three replicate plates are given

number of revertants with $1,000 \mu \mathrm{g}$ CS per plate as compared to control. This dose-dependence vanished with increasing concentrations of S-9 added.

A comparison of the data obtained without (Table 2, Fig. 1) and with (Table 3, Fig. 2) pre-incubation revealed the higher sensitivity of the latter method with respect to the number of revertants but also with respect to the cytotoxicity of the compound under investigation.

In order to find out whether the weak mutagenicity detected in strain TA 100 would be more pronounced if cell survival was accounted for, the number of surviving cells as a function of the dose of CS was determined. Without pre-incubation (Fig. 3), a decrease to about two thirds in cell survival was observed between 1 and $2 \mathrm{mg} \mathrm{CS}$, a bactericidal effect which could not be counteracted by the addition of increasing concentration of S-9. With pre-incubation (Fig. 4), the addition of $100 \mu \mathrm{g}$ per plate already strongly reduced cell survival. Here, the toxic effects of CS were partially overcome by the addition of $\mathrm{S}-9$.

The toxic effects of $\mathrm{CS}$ were also revealed by the growth inhibition of resistant colonies. After incubation for 2 days at $37^{\circ} \mathrm{C}$ only small colonies were formed on plates containing 1,000 and 2,000 $\mu \mathrm{g} \mathrm{CS}$. Colonies could only be counted after 3 days.

If the mutagenic effects are expressed as mutation frequencies (number of mutants per number of surviving cells) the mutagenic effects of CS increase by a factor of two in the plate incorporation assay as a result of the reduction of cell survival. Upon pre-incubation, this situation seems to be more pronounced and the slight increase in the number of revertants observed in the absence of S-9 
A. von Däniken et al.

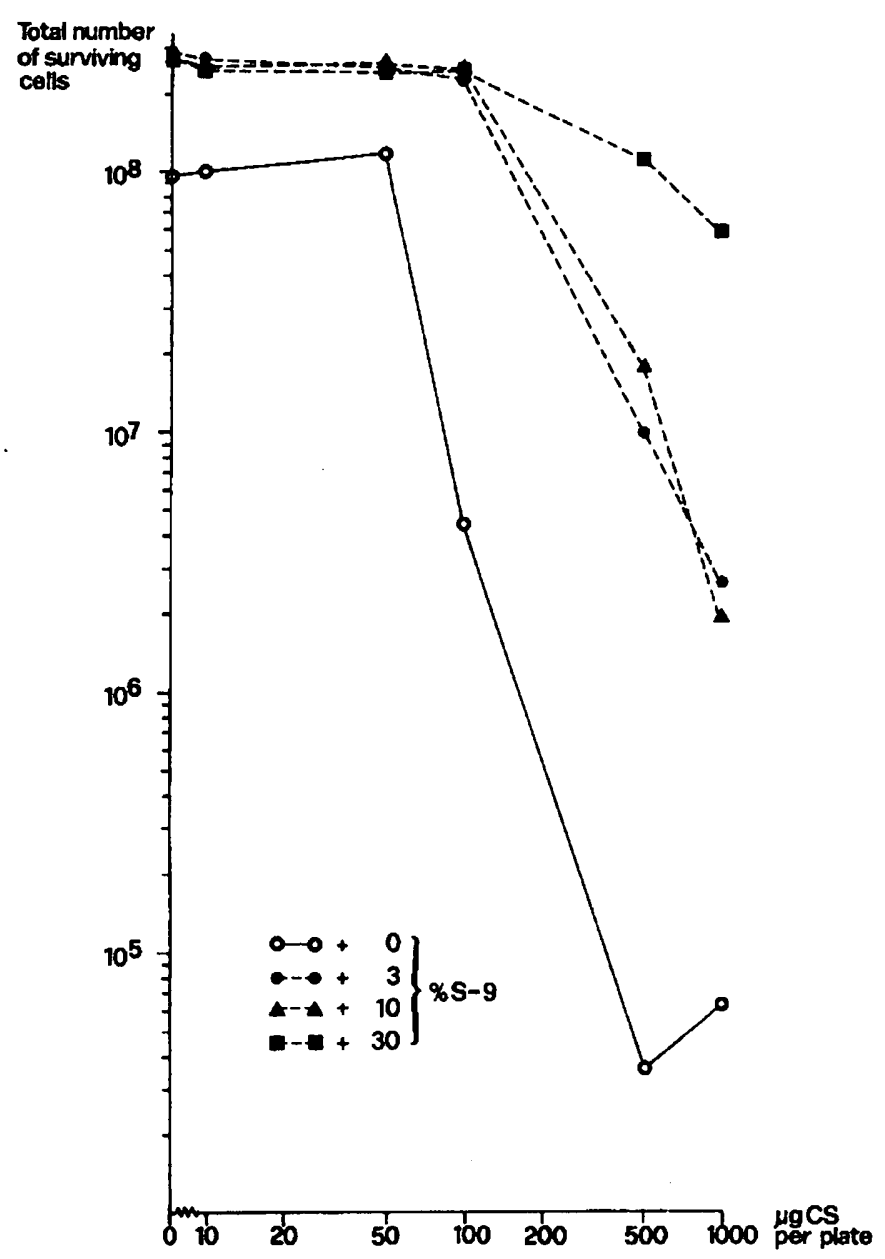

Fig. 4. Bactericidal effects of CS. CS was pre-incubated with bacteria and appropriate dilutions of S-9 before plating on minimum medium plates supplemented with additional histidine. Mean values of three replicate plates are given

between 10 and $50 \mu \mathrm{g}$ per plate (Fig. 2) continues beyond this dose if the marked decrease in the number of surviving cells at doses of $100 \mu \mathrm{g}$ and more (Fig. 4) is taken into account.

\section{Discussion}

Our results show that CS can undergo a covalent interaction with rat nuclear protein in liver and kidney in vivo, but no reaction with the DNA of these organs could be measured. CS or its metabolites can therefore reach the nuclei of liver and kidney in a chemical form which is reactive only towards protein but not towards nucleic acid. The ratio of protein binding to DNA binding is more than 100 on a weight basis. This difference might be due to the selectivity of CS to react with an appropriate reacting partner. The double bond of CS is rendered slightly electrophilic because of the strongly electron withdrawing substituents. It therefore seems to react preferentially with SH-groups of protein (Cucinell et al. 1971). In addition, the radiolabelled hydrolysis product of CS, o-chloro- 
benzaldehyde, might have reacted with amino groups of protein. Protein binding is probably responsible for cytotoxic effects of chemicals (Gillette 1974; Reid et al. 1973; Schumann et al. 1980) but seems to be less directly involved in the process of tumor induction than is DNA binding (Brookes and Lawley 1964). For instance, another typical $\mathrm{SN}_{2}$-reactive compound, iodoacetamide, reacts with protein but not with DNA and has never been shown to be carcinogenic (Lawley and Brookes 1968).

Radioactivity on DNA was on a very low level or even below the limit of detection. The calculated Covalent Binding Index (CBI) was at the most $0.16 \pm 0.12$ for liver $(75 \mathrm{~h})$ and $<0.85$ for kidney $(75 \mathrm{~h})$. These values must be compared with that of known carcinogens. The CBI of the strong hepatocarcinogen aflatoxin $B_{1}$ is approximately 10,000 and that of vinyl chloride, another known carcinogen is around 500. More conspicuously, an equal radioactivity dose administered in the form of vinyl chloride instead of CS would have resulted in a specific activity of $3,600 \mathrm{dpm} / \mathrm{mg}$ liver DNA due to covalent binding.

CBI's in the order of 1 were found for the weakest or suspected carcinogens like benzene (review by Lutz 1979). The binding of CS, if there is any at all, therefore lies below the region of the weakest initiating carcinogens.

As a first approximation, a Covalent Binding Index is a dose-independent, only compound-related figure. First order kinetics seem to prevail for the binding of genotoxic carcinogens to biological macromolecules in vivo down to very small doses, as was shown with trans-4-dimethylaminostilbene (Neumann 1980). A linear dose-binding relationship was found down to as little as $25 \mathrm{ng}$ chemical administered per rat.

For the estimation of the quantity of DNA damage, i.e., for an estimation of the risk for cancer, the actual dose has to be taken into account. We estimate a maximal intake of about $1 \mathrm{mg}$ per man after an acute inhalation of air containing $200 \mathrm{mg} / \mathrm{m}^{3}$, a concentration that may be generated after an attack with an aerosol spray. This is extremely minute as compared with the intake of other toxic substances such as vinyl chloride by polymerization workers, where the daily intake of more than $1 \mathrm{~g}$ over several years produced in about $0.2 \%$ of these workers a haemangiosarcoma of the liver (Selikoff and Hammond 1975). This comparison means that not only the DNA-interacting potency of CS is at least three orders of magnitude weaker than that of vinylchloride, but also that the actual exposure differs by many orders of magnitude.

The mutagenicity data suggest that CS can interact with bacterial DNA. As could be expected on the basis of its chemical reactivity, CS is mutagenic without addition of S-9. Only TA 100 yielded a positive response. This strain contains the plasmid pKM 101 which makes it more sensitive as compared with its parent strain TA 1535, an indicator strain for base pair substitutions. Also, large amounts of CS were needed to produce a slight effect, e.g., a $4 \times$ enhancement of the spontaneous mutation frequency with $2,000 \mu \mathrm{g} C S$ per plate. CS can therefore be called very weakly mutagenic for Salmonella. In the presence of mammalian cell components, the mutagenic activity vanished. CS was markedly bactericidal. As expected, this toxicity was most pronounced in bacteria pre-incubated with the test compound in the absence of S-9. Addition of 
A. von Däniken et al.

increasing amounts of S-9 reduced the bacteriotoxicity, perhaps as the result of a binding of CS to protein, an activity which was also observed in vivo.

The data presented above suggest that CS cannot exhibit a carcinogenic activity induced by DNA binding. Taking also into account the rare and low exposure of humans, the risk for the induction of point mutations and for the carcinogenic process derived thereof must be regarded negligible.

Acknowledgement. We thank Ms. Doris Hann for her valuable help with the Ames test and for the line drawings.

\section{References}

Ames BN, McCann J, Yamasaki E (1975) Methods for detecting carcinogens and mutagens with the Salmonella/mammalian-microsome mutagenicity test. Mutat Res 31:347-364

Anonymous (1973) Tests on CS for carcinogenicity. Br Med J 20:129

Ballantyne B, Swanston DW (1978) The comparative acute mammalian toxicity of 1-chloracetophenone (CN) and 2-chlorobenzylidene malononitrile (CS). Arch Toxicol 40: 75-95

Barry DH, Chasseaud LF, Hunter B, Robinson WE (1972) The suppression of non-specific esterase activity in mouse skin sebaceous gland by CS gas. Nature 240:560-561

Brookes P, Lawley PD (1964) Reaction of some mutagenic and carcinogenic compounds with nucleic acids. J Cell Comp Physiol [Suppl 1] 64:111-128

Cucinell SA, Swentzel KC, Biskup R, Snodgrass H, Lovre S, Stark W, Feinsilver L, Vocci F (1971) Biochemical interactions and metabolic fate of riot control agents. Fed Proc 30:86-91

Gaskins JR, Hehir RM, McCaulley DF, Ligon EW (1972) Lacrimating agents (CS and CN) in rats and rabbits. Arch Environ Health $24: 449-454$

Gillette JR (1974) A perspective on the role of chemically reactive metabolites of foreign compounds in toxicity. Biochem Pharmacol 23: 2785-2794

Harrison JM, Inch TD, Lawston IW, Ley RV, Sainsbury GL (1978) The synthesis of $\left[{ }^{3} \mathrm{H}\right]$ and $\left[{ }^{14} \mathrm{C}\right] \mathrm{o}$-chlorobenzylidene malononitrile (CS). J Lab Comp 14:141-148

Jones GRN (1972) CS and its chemical relatives. Nature 235:257-261

Jones R (1973) More doubts about CS. New Scientist 57:61

Lawley PD, Brookes P (1968) Cytotoxicity of alkylating agents towards sensitive and resistant strains of Escherichia coli in relation to extent and mode of alkylation of cellular macromolecules and repair of alkylation lesions in deoxyribonucleic acids. Biochem J 109: 433-445

Lowry OH, Rosebrough NJ, Farr AL, Randall RJ (1951) Protein measurement with the folin phenol reagent. J Biol Chem 193:265-275

Lutz WK (1979) In vivo covalent binding of organic chemicals to DNA as a quantitative indicator in the process of chemical carcinogenesis. Mutat Res $65: 289-356$

Lutz WK (1981) Constitutive and carcinogen-derived DNA binding as a basis for the assessment of potency of chemical carcinogens. In: Snyder R, Parke DV, Kocsis J, Jollow DJ, Gibson GG (eds) Biological reactive intermediates, chemical mechanisms and biological effects. Plenum Press, New York, in press

Markov GG, Ivanov IG (1974) Hydroxyapatite column chromatography in procedures for isolation of purified DNA. Anal Biochem 59:555-563

McNamara BP, Renne RA, Rozmiarek H, Ford DF, Owens EJ (1973) CS; A study of carcinogenicity. Nat Technic Inf Service (US Dept of Commerce) ISS No AD $770: 365 / 5 \mathrm{GA}$

Nagao M, Yanagi T, Seino Y, Sugimura T, Ito N (1977) Mutagenicities of quinoline and its derivatives. Mutat Res 42:335-342

Neumann HG (1980) Dose-response relationship in the primary lesion of strong electrophilic carcinogens. Arch Toxicol [Suppl] 3:69-77

Purchase IFH, Longstaff E, Ashby J, Styles JA, Anderson D, Lefevre PA, Westwood FR (1976) Evaluation of six short term tests for detecting organic chemical carcinogens and recommendations for their use. Nature $264: 624-627$ 
Reid WD, Krishna G, Gillette JR, Brodie BB (1973) Biochemical mechanisms of hepatic necrosis induced by aromatic hydrocarbons. Pharmacology 10:193-214

Sanford JP (1976) Medical aspects of riot control (harassing) agents. Annu Rev Med 27: $421-429$

Schrempf A (1978) Chemical mace - Wie gefährlich ist Chloracetophenon? Chemie in unserer Zeit 12: $146-152$

Schumann AM, Quast JF, Watanabe PG (1980) The pharmacokinetics and macromolecular interactions of perchloroethylene in mice and rats as related to oncogenicity. Toxicol Appl Pharmacol 55: 207-219

Selikoff IJ, Hammond EC (eds) (1975) Toxicity of vinyl chloride-polyvinyl chloride. Ann NY Acad Sci 246: $1-337$

Viviani A, Lutz WK, Schlatter C (1978) Time course of the induction of aryl hydrocarbon hydroxylase in rat liver nuclei and microsomes. Biochem Pharmacol 27: 2103-2108

Received January 22, 1981 